\title{
How to Conduct an On-farm Dye Test and Use the Results to Improve Drip Irrigation Management in Vegetable Production 1
}

\section{Eric Simonne, David Studstill, Michael Dukes, John Duval, Robert Hochmuth, Gene McAvoy, Teresa} Olczyk, Steve Olson, Elizabeth Lamb²

Improving irrigation management in vegetable crop production reduces production costs, saves water, and reduces the risk of nutrient leaching. As water movement in the root zone below mulched beds is difficult to see, injecting soluble dye through the drip irrigation system provides a simple and practical method to visualize water movement in the soil. Understanding water movement in raised beds is essential for improving irrigation scheduling and nutrient delivery. Proper irrigation scheduling requires a target irrigation volume, a measure of soil moisture, knowledge of how much water the root zone can hold, and a method to account for rainfall contribution to replenishing soil moisture. By showing how deep and how wide water moves in mulched beds as irrigation volume increases, dye tests are practical tools for determining how much water can be held in the root zone. This information is then used to determine how to split irrigation events and better manage irrigation. Results and pictures of dye tests conducted at the North Florida Research and Education Center - Suwannee Valley near Live Oak,
FL on a Lakeland fine sand may be accessed at http://nfrec-sv.ifas.ufl.edu/ (click on Irrigation Management, and Dye Study Photo Gallery).

\section{Procedures for Conducting a Dye Test}

A dye test requires meticulous planning and preparation (steps 1 to 7 in Table 1). It is important to conduct the dye test under conditions similar to actual production conditions so that water movements observed after the dye test are representative of those occurring during crop production. Since water volumes applied are a function of irrigation time and drip tape flow rate, it may be useful to select and test more than one drip tape type (manufacturer, emitter spacing, and flow rate) and use 1 or 2 drip tapes on each bed. Irrigation times should be selected to cover the range of typical irrigation times used during the crop cycle. It is essential to realize that although irrigation time and irrigation volume are often used interchangeably

1. This document is HS980 one of a series of the Horticultural Sciences Department, Florida Cooperative Extension Service, Institute of Food and Agricultural Sciences, University of Florida. Publication date: July 2004. Please visit the EDIS Web site at http://edis.ifas.ufl.edu.

2. Eric Simonne, assistant professor, David Studstill, biologist, Horticultural Sciences Department; Michael Dukes, assistant professor, Agricultural and Biological Engineering Department; John Duval, assistant professor, GCREC-Dover; Gene McAvoy, extension agent III, Hendry County; Teresa Olczyk, extension agent III, Miami-Dade County-South, Steve Olson, professor, NFREC-Quincy, Elizabeth Lamb, assistant professor, IRREC-Ft. Pierce, Cooperative Extension Service, Institute of Food and Agricultural Sciences, University of Florida, Gainesville, 32611

The Institute of Food and Agricultural Sciences (IFAS) is an Equal Employment Opportunity - Affirmative Action Employer authorized to provide research, educational information and other services only to individuals and institutions that function without regard to race, creed, color, religion, age, disability, sex, sexual orientation, marital status, national origin, political opinions or affiliations. For information on obtaining other extension publications, contact your county Cooperative Extension Service office. Florida Cooperative Extension Service / Institute of Food and Agricultural Sciences / University of Florida / Larry R. Arrington, Interim Dean 


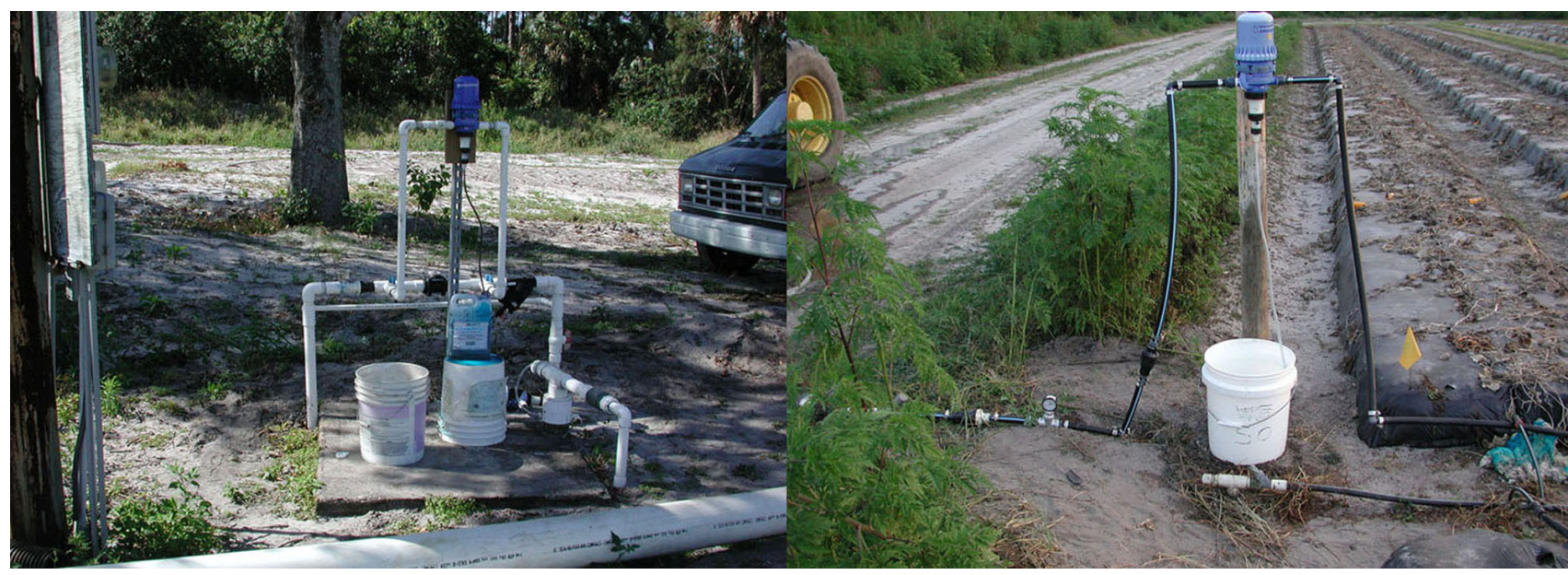

Figure 1. Example of injection loops using a Dosatron (left) or a Mazzei injector (right).

(rightfully so for a known flow rate), the movement of the waterfront depends on irrigation volume applied (in gallons/100 lbf), not irrigation time itself. The existing drip irrigation system may need to be modified so only a small area of the field is used for the dye test (Table 2).

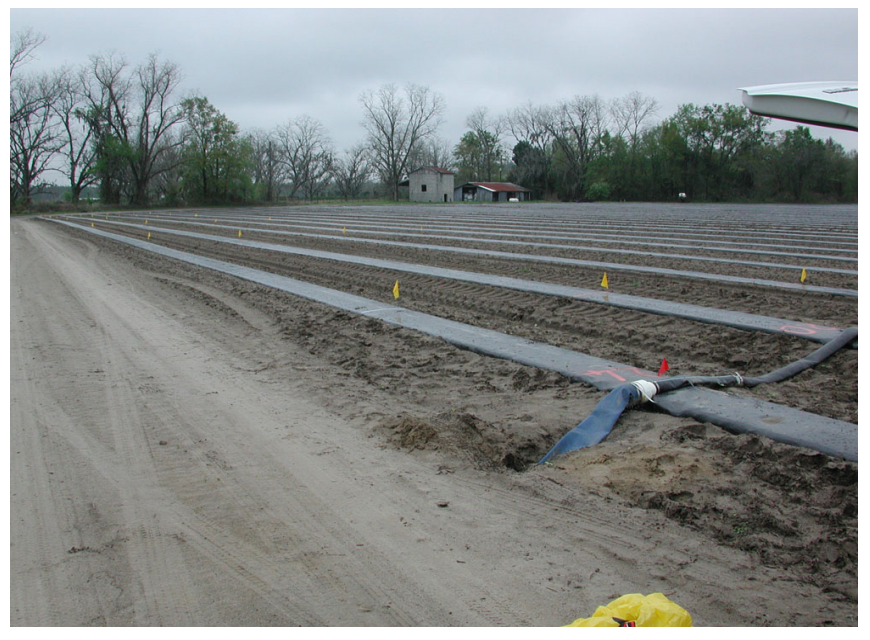

Figure 2. Example of possible layout for a dye test.

For practical purposes, the dye field will be divided into beds (where different drip tapes will be used). Each bed will also be divided into sections corresponding to each of the irrigation times selected (Fig. 1). Dye selection (step 5, Table 1) is a critical step. Since the interpretation of the dye test assumes that the dye moves with the water front, selected dye should be totally soluble and not adsorbed by soil particles or soil organic matter. On the day of the dye test (steps 8 to 12, Table 1), consider starting early so that the entire test may be conducted during the same day. Once the system is operating, inject the dye and tie the drip tapes at the pre-determined times. Dye may be injected with a Dosatron or Mazzi injector. The shortest irrigation times will be located away from the water source, and increasingly longer irrigation times will be closer to the water source (Fig. 2).

Pressure monitoring during the dye test is important, especially each time a section is tied off. As time progresses, the length of the remaining drip tape is shortened in the irrigation system, which may result in increased pressure and water flow. Volumes delivered by the drip system should be monitored according to operating time and/or with the water meter (Table 2). Pressure and water flow should be kept as constant as possible during the entire test to ensure that operating conditions match those recommended by manufacturers.

\section{Data Collection and Observation of the Dye Pattern}

After the dye test, longitudinal and transverse sections should be carefully dug for each drip tape and each operating time (step 13, Table 1). This may be the most time consuming step. Each dye pattern will appear as a blue ring below each emitter (Fig. 3). The dye pattern may appear faded immediately after digging. However, the contrast between the colored areas and the remaining soil will improve as the bed dries out. When dye is injected during the entire test, all the wetted area is colored in blue. Observe the shape of the wetted zone (Fig. 4): is it round or elongated? Did the dye move outside the bed? When 


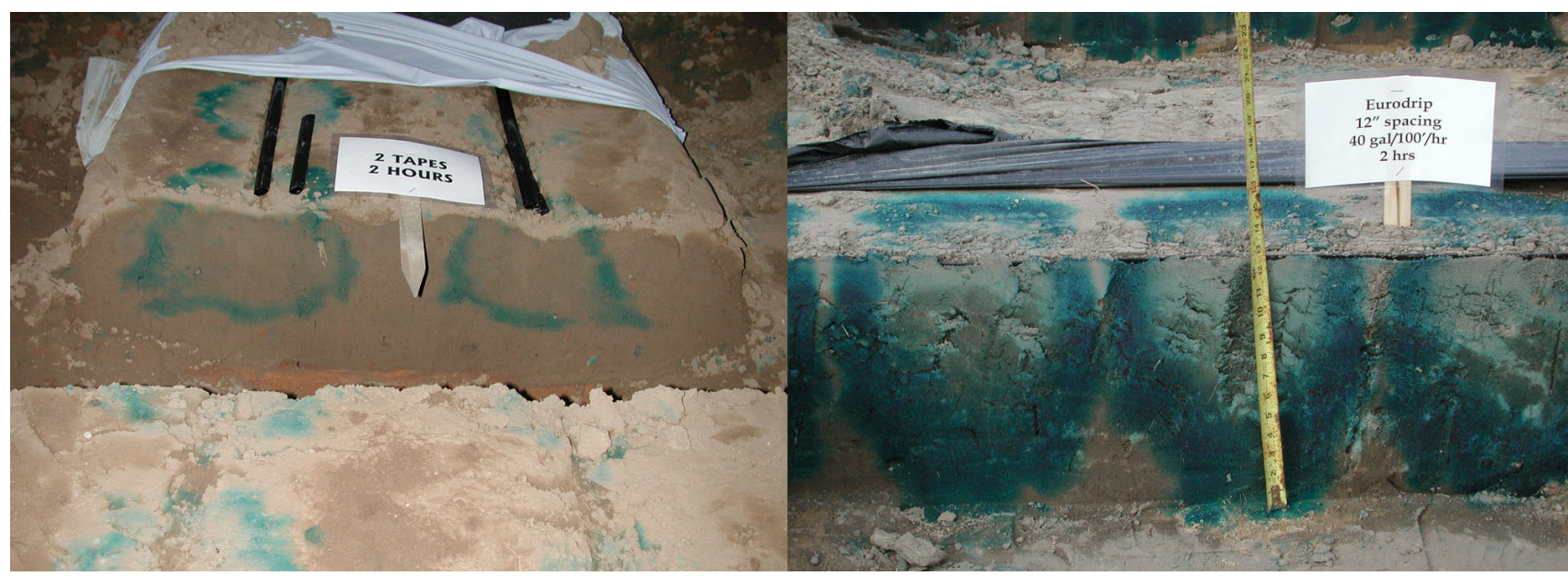

Figure 3. Sample dye pattern on transverse (left) and longitudinal (right) sections.

did emitter-to-emitter coverage occur? When did the dye pass below the root zone (12 inches)? When did the dye reach the impermeable layer? How did the water move then? What is the size and shape of the wetted zone under typical irrigation times?

After observation, measurements of length, depth and width of the wetted zone should be carefully made (step 14, Table 1) and recorded (Table 3). Pictures may also be taken to provide a permanent record of the dye test.

\section{Using Dye Movement Information for Improving Irrigation Management}

While observation provides qualitative information, quantitative measures are needed to improve irrigation management. Important wetting characteristics are maximum wetted width, shortest time (or volume) needed for emitter-to-emitter coverage, and time (or volume) when water reaches the bottom of the root zone (Table 4). Each irrigation event has to be a compromise between providing moisture to the crop and minimizing off-site water movement.

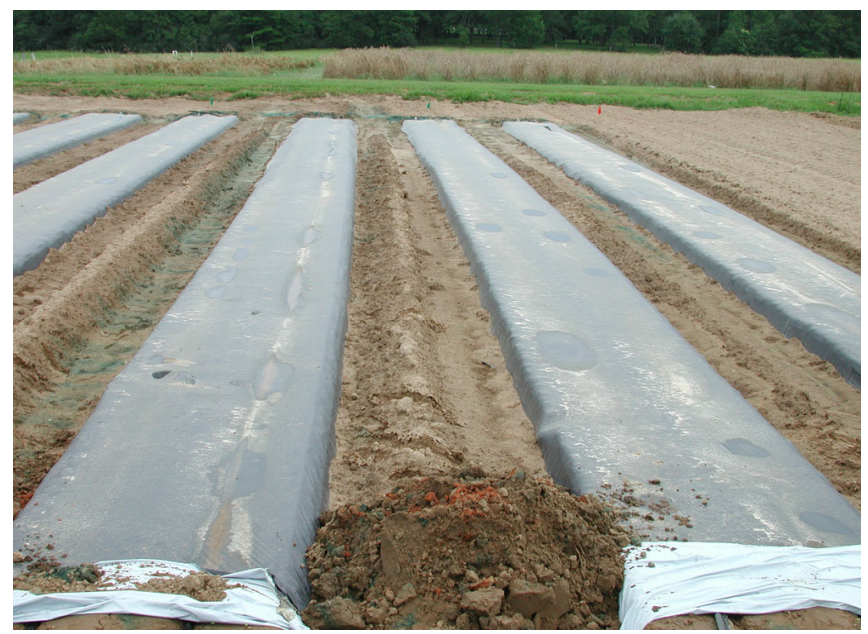

Figure 4. Water redistribution in the presence of an impermeable layer. In Quincy, FL on an Orangeburg loamy sand, dye appeared in the alleys (a). In Hendry county, the wetted zone has an omega shape when the water front reaches the impermeable layer (b). 
Table 1. Step-by-step operations needed to conduct an on-farm dye test.

\begin{tabular}{|c|c|c|c|}
\hline When & Step No. & Operation & Comment \\
\hline \multirow[t]{7}{*}{$\begin{array}{l}\text { Before the day of } \\
\text { the dye test }\end{array}$} & 1 & $\begin{array}{l}\text { Prepare the field and form } \\
\text { the beds as will be done for } \\
\text { vegetable production. }\end{array}$ & $\begin{array}{l}\text { Read drip tape information provided by the manufacturer; } \\
\text { record nominal flow rates, operating pressure, and } \\
\text { maximum bed length. If two drip tapes are used, calculate } \\
\text { the 'apparent flow rate' by multiplying by two the drip tape } \\
\text { nominal flow rate. } \\
\text { Flush irrigation system as recommended. }\end{array}$ \\
\hline & 2 & $\begin{array}{l}\text { Isolate a section of the field } \\
\text { where the dye test will be } \\
\text { performed. }\end{array}$ & $\begin{array}{l}\text { Select a representative area of the field close to a water } \\
\text { source. Area selected should be between } 1,000 \text { to } 2,000 \\
\text { linear bed feet. }\end{array}$ \\
\hline & 3 & $\begin{array}{l}\text { Connect the water source } \\
\text { to the section of the field } \\
\text { where the dye test will be } \\
\text { performed. }\end{array}$ & $\begin{array}{l}\text { Because this section may be much smaller than the entire } \\
\text { field, a } 3 / 4 \text { to } 1 \text { inch poly-pipe may be temporarily used to } \\
\text { supply water to this section. }\end{array}$ \\
\hline & 4 & $\begin{array}{l}\text { Prepare an injection point } \\
\text { for the dye. }\end{array}$ & $\begin{array}{l}\text { The injection point should be close to the field section } \\
\text { where the dye will be injected ( } 5 \text { to } 15 \mathrm{ft}) \text {. } \\
\text { Components of the injection manifold are described in } \\
\text { table } 2 \text {. }\end{array}$ \\
\hline & 5 & $\begin{array}{l}\text { Select a water-soluble } \\
\text { dye. }\end{array}$ & $\begin{array}{l}\text { While several dyes are available on the market, } \\
\text { satisfactory results have been achieved with the blue } \\
\text { Dynamark U.V. dye. Always read and follow the label. } \\
\text { Dye costs approximately } \$ 40 / \text { gallon. Dyes are highly } \\
\text { concentrated and should be used with care. }\end{array}$ \\
\hline & 6 & $\begin{array}{l}\text { Mark bed sections } 30 \text { to } 50 \\
\text { feet in length. Sections } \\
\text { may be marked with flags or } \\
\text { paint. Select a few } \\
\text { representative operating } \\
\text { times. }\end{array}$ & $\begin{array}{l}\text { Each section will correspond to a different operating time. } \\
\text { Operating times should represent the different irrigation } \\
\text { lengths used throughout the season. For example, } \\
\text { possible operating times are } 1,2,3,4,6 \text {, and } 8 \text { hours. } \\
\text { Operating times of } 1 \text { to } 4 \text { hours represent irrigation times, } \\
\text { while } 6 \text { and } 8 \text { hours represent excessive irrigations or } \\
\text { irrigations needed to apply fumigants. }\end{array}$ \\
\hline & 7 & Flush the system. & $\begin{array}{l}\text { Essential if system was left idle for few days after } \\
\text { installation. }\end{array}$ \\
\hline \multirow[t]{5}{*}{$\begin{array}{l}\text { On the day of the } \\
\text { dye test }\end{array}$} & 8 & $\begin{array}{l}\text { Bring stop watch, data } \\
\text { collection form and pen, a } \\
\text { knife, a tape measure and } \\
\text { shovels. }\end{array}$ & $\begin{array}{l}\text { Stop watch will be used to keep track of irrigation times; } \\
\text { data collection form will be used to record time and } \\
\text { irrigation volume applied (based on water meter readings); } \\
\text { the tape measure will be used to measure the wetting } \\
\text { zone. }\end{array}$ \\
\hline & 9 & Bring a 5-gallon bucket & May be used to pre-dilute concentrated dye. \\
\hline & 10 & $\begin{array}{l}\text { Turn on the water and } \\
\text { pressurize system. }\end{array}$ & $\begin{array}{l}\text { Read and record pressures at gauges. } \\
\text { Check and repair leaks in the field }\end{array}$ \\
\hline & 11 & $\begin{array}{l}\text { Start injecting dye once } \\
\text { system has been charged }\end{array}$ & Read and record time and initial reading on water meter \\
\hline & 12 & $\begin{array}{l}\text { At pre-selected times (see } \\
\text { step 6), cut and tie the } \\
\text { tapes at pre-marked spots } \\
\text { (see step 6). }\end{array}$ & $\begin{array}{l}\text { Sections receiving the shortest irrigation times should be } \\
\text { placed at the farthest end of the test. } \\
\text { Monitor pressure changes at gauges } 1,2 \text {, and } 3 \text { after each } \\
\text { section is tied. }\end{array}$ \\
\hline
\end{tabular}


How to Conduct an On-farm Dye Test and Use the Results to Improve Drip Irrigation....

Table 1. Step-by-step operations needed to conduct an on-farm dye test.

\begin{tabular}{||l|c|l|l||}
\hline \hline When & Step No. & \multicolumn{1}{|c|}{ Operation } & \multicolumn{1}{c|}{ Comment } \\
\hline After the dye test & 13 & $\begin{array}{l}\text { For each section, dig a } \\
\text { transverse (perpendicular } \\
\text { to the bed axis) and a 4-foot } \\
\text { longitudinal (parallel to the } \\
\text { bed axis) section. }\end{array}$ & $\begin{array}{l}\text { Holes should be deep enough to see the bottom of the } \\
\text { dye. The dye may appear fade immediately after digging, } \\
\text { but soil drying will improve contrast. When digging, } \\
\text { always select the sides best exposed to direct sun light so } \\
\text { that soil will dry faster. }\end{array}$ \\
\cline { 2 - 5 } & 14 & $\begin{array}{l}\text { Measure and record the } \\
\text { position of the water front } \\
\text { for each visible emitter. }\end{array}$ & $\begin{array}{l}\text { Observe the shape of the dye pattern; notice uniformity. } \\
\text { Record depth and width on transverse bed sections, and } \\
\text { depth and length on the longitudinal bed sections. Note } \\
\text { that different numbers of emitters (and therefore } \\
\text { measurements) may be done on the transverse and } \\
\text { longitudinal sections. }\end{array}$ \\
\cline { 2 - 4 } & 15 & $\begin{array}{l}\text { Disconnect the injection } \\
\text { point to allow drip irrigation } \\
\text { system to operate } \\
\text { normally }\end{array}$ & $\begin{array}{l}\text { The execution of the dye test should not have long-term } \\
\text { effects on drip system operation and design. }\end{array}$ \\
\hline \hline
\end{tabular}


How to Conduct an On-farm Dye Test and Use the Results to Improve Drip Irrigation....

Table 2. Description of the injection manifold (from water source to field).

\begin{tabular}{|c|c|c|}
\hline Component & Role & Relative importance \\
\hline On-off valve & Control water supply. & Essential \\
\hline Pressure gauge 1 & $\begin{array}{l}\text { Monitor changes in pressure of water source. } \\
\text { In-coming pressure should be in the } 40 \text { to } 50 \text { psi. }\end{array}$ & Practical \\
\hline $\begin{array}{l}\text { Back-flow prevention } \\
\text { device }\end{array}$ & $\begin{array}{l}\text { Prevent water and dye to be siphoned back into the } \\
\text { water source. }\end{array}$ & $\begin{array}{l}\text { Essential (mandated by } \\
\text { Florida Statutes) }\end{array}$ \\
\hline In-line faucet & Outside supply of water. & $\begin{array}{l}\text { Very practical when no other } \\
\text { water source is available }\end{array}$ \\
\hline Water meter & Record water volume applied. & Essential \\
\hline In-line screen filter & Reduce risk of clogging. Improves uniformity. & Useful \\
\hline Pressure reducer & $\begin{array}{l}\text { Maintain pressure close to drip-tape manufacturer } \\
\text { operating pressure. Ensures proper flow rate and } \\
\text { improves uniformity. }\end{array}$ & Essential \\
\hline Pressure gauge 2 & $\begin{array}{l}\text { Monitor changes in water pressure before the injection } \\
\text { point }\end{array}$ & Practical \\
\hline $\begin{array}{l}\text { Injection point (Mazzi- or } \\
\text { Dosatron-type (Fig. 2) }\end{array}$ & $\begin{array}{l}\text { Inject the dye in the system. Use a } 1: 50 \text { to } 1: 100 \\
\text { dilution rate. Insert weight and a filter at the end of the } \\
\text { suction line. }\end{array}$ & Essential \\
\hline Pressure gauge 3 & $\begin{array}{l}\text { Monitor changes in pressure at the furthest point of the } \\
\text { system. }\end{array}$ & Practical \\
\hline
\end{tabular}

Table 3. Sample data collection form for recording the effect of drip tape and irrigation length on water movement.

\begin{tabular}{|c|c|c|c|c|c|c|}
\hline $\begin{array}{l}\text { Operating } \\
\text { time (hour) }\end{array}$ & $\begin{array}{c}\text { Drip tape } \\
\text { (Manufacturer, } \\
\text { flow rate, } \\
\text { emitter } \\
\text { spacing) }\end{array}$ & $\begin{array}{c}\text { No. of drip } \\
\text { tape/bed }\end{array}$ & $\begin{array}{l}\text { Total water } \\
\text { applied }^{1} \\
\text { (gallon/100 ft) }\end{array}$ & $\begin{array}{l}\text { Depth }^{2} \\
\text { (in) }\end{array}$ & $\begin{array}{c}\text { Width }^{3} \\
\text { (in) }\end{array}$ & $\begin{array}{l}\text { Length } \\
\text { (in) }\end{array}$ \\
\hline \multirow[t]{3}{*}{1} & Tape A & 1 & & & & \\
\hline & Tape B & 1 & & & & \\
\hline & Tape B & 2 & & & & \\
\hline \multirow[t]{3}{*}{2} & Tape A & 1 & & & & \\
\hline & Tape B & 1 & & & & \\
\hline & Tape B & 2 & & & & \\
\hline \multirow[t]{3}{*}{3} & Tape A & 1 & & & & \\
\hline & Tape B & 1 & & & & \\
\hline & Tape B & 2 & & & & \\
\hline
\end{tabular}


Table 3. Sample data collection form for recording the effect of drip tape and irrigation length on water movement.

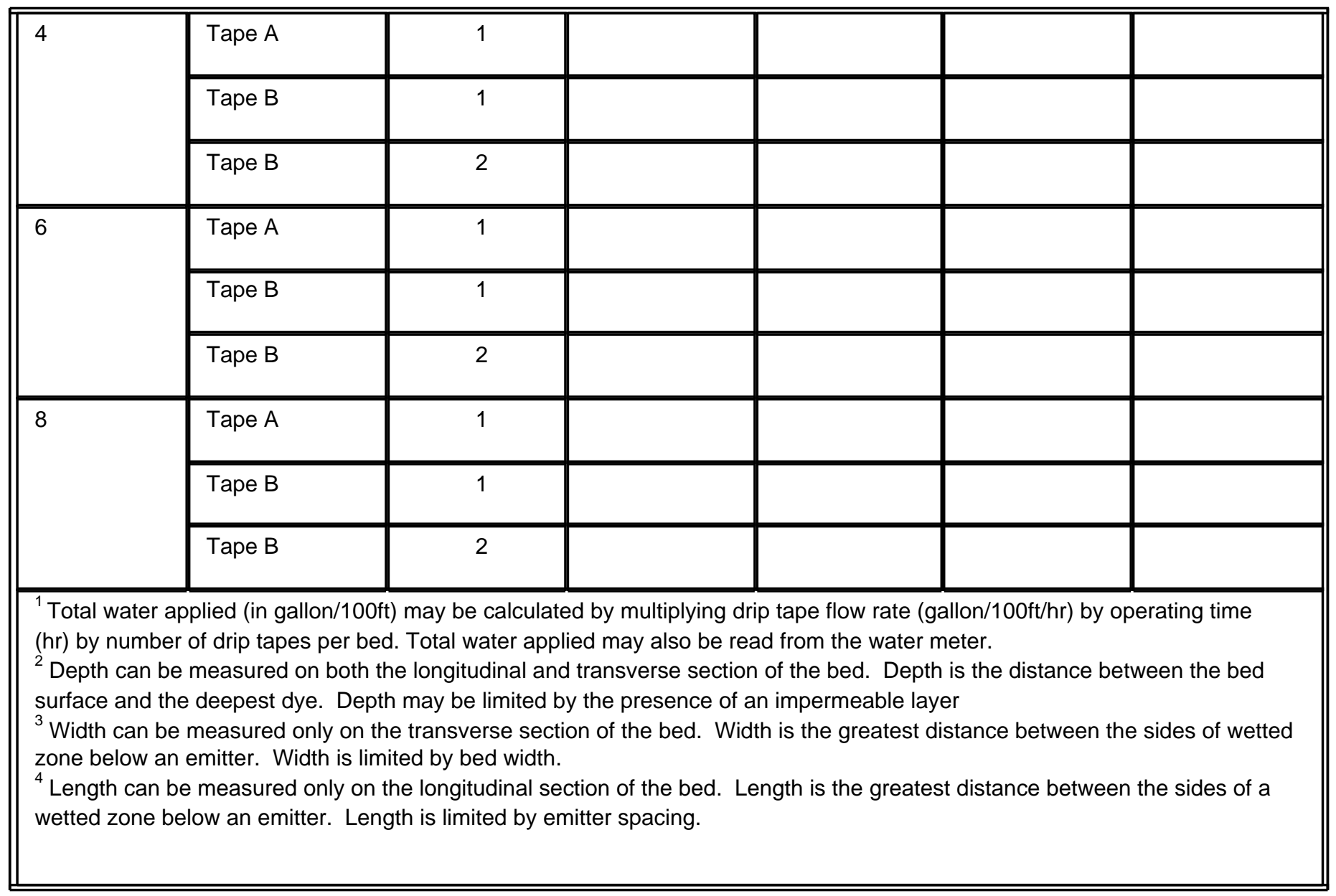

Table 4. Calculating, interpreting, important wetting characteristics and their application in irrigation scheduling.

\begin{tabular}{||l|l|l||}
\hline \hline $\begin{array}{l}\text { Wetting } \\
\text { characteristic }\end{array}$ & \multicolumn{1}{|c||}{ Measurement/calculation } \\
\hline $\begin{array}{l}\text { Maximum wetted } \\
\text { width (Wmax) }\end{array}$ & $\begin{array}{l}\text { Measured from dye pattern } \\
\text { Relative wetted width (\%) } \\
\text { wetted width (Wmax, in } \\
\text { inches) / bed width (in inches) } \\
\times 100\end{array}$ & $\begin{array}{l}\text { An Florida's sandy soils, Wmax is typically 14 to 16 inches. } \\
\text { Highest possible relative wetted width is needed to improve } \\
\text { the efficiency of injected fumigants. Increasing irrigation } \\
\text { time or volume in an attempt to increase wetted width will not } \\
\text { work. Wetted width may only be increased by increasing } \\
\text { bed compaction or increasing soil organic matter content. } \\
\text { Relative wetted width may be increased by decreasing bed } \\
\text { width. } \\
\text { Vegetable crops should not be seeded or transplanted } \\
\text { outside the wetted width. When plants are small, irrigation } \\
\text { should ensure that the wetted front reaches the plants or the } \\
\text { seeds }\end{array}$ \\
& & $\begin{array}{l}\text { In Florida's sandy soils, complete emitter-to-emitter } \\
\text { coverage typically occurs in 1 hr for 4-inch emitter spacings } \\
\text { and 2 hours for } 8 \text { and 12-inch emitter spacings. Complete } \\
\text { emitter-to-emitter coverage provides water uniformly and } \\
\text { contributes to crop uniformity. }\end{array}$ \\
\hline $\begin{array}{l}\text { Shortest time for } \\
\text { emitter-to-emitter } \\
\text { coverage }\end{array}$ & Measured from dye pattern \\
& & \\
\hline
\end{tabular}


Table 4. Calculating, interpreting, important wetting characteristics and their application in irrigation scheduling.

\begin{tabular}{|c|c|c|}
\hline $\begin{array}{l}\text { Wetting } \\
\text { characteristic }\end{array}$ & Measurement/calculation & Application in irrigation management \\
\hline $\begin{array}{l}\text { Time when water } \\
\text { depth becomes } \\
\text { greater than the root } \\
\text { zone (Fig. } 4 \text { ) }\end{array}$ & Measured from dye pattern & $\begin{array}{l}\text { Most important wetting parameter from nutrient leaching and } \\
\text { water savings standpoint. Adequate irrigation management } \\
\text { does not use irrigation events resulting in the water front } \\
\text { moving below the bottom of the root zone. In Florida sandy } \\
\text { soils, a soil section } 1 \text { foot wide, } 1 \text { foot deep and } 100 \text { foot long } \\
\text { can typically hold } 30 \text { gallons of available water. } \\
\text { In fields without an impermeable layer, water moves } \\
\text { vertically until it reaches the water table. The risk of nutrient } \\
\text { leaching is high. When vegetable crops need large amounts } \\
\text { of water that may result in nutrient leaching, irrigation should } \\
\text { be split into two or three } 2 \text {-hr events during the same day. } \\
\text { In fields with an impermeable layer, water moves laterally } \\
\text { once it reaches the impermeable layer. It then moves } \\
\text { horizontally by gravity and vertically by capillarity. The } \\
\text { entire field may be wetted, and nutrients may move between } \\
\text { the rows. Irrigation has to be a compromise between } \\
\text { providing moisture to the entire field and off-site water and } \\
\text { nutrient movement. }\end{array}$ \\
\hline
\end{tabular}

